\title{
Local production of rotavirus specific IgA in breast tissue and transfer to neonates
}

\author{
M M RAHMAN, M YAMAUCHI, N HANADA, K NISHIKAWA, AND T MORISHIMA \\ Department of Pediatrics, Nagoya University School of Medicine, Nagoya, Japan
}

SUMMARY Rotavirus specific IgA, secretory component, and IgG were measured by enzyme linked immunosorbent assay in 20 pairs of mothers and babies to estimate antibody transfer from the mother, particularly from breast milk to neonatal faeces. Colostrum contained high titres of specific IgA and secretory component, which decreased gradually. Faeces after breast feeding for three days showed detectable titres of $\operatorname{IgA}$ and secretory component, with further increases by seven days. There was a positive correlation between titres of secretory component in breast milk and in faeces. To clarify the mechanism of high anti-rotavirus activity in breast milk, ratios of rotavirus specific IgA in maternal serum samples to breast milk were calculated and compared with those that were herpes simplex virus specific. Significantly higher concentrations were obtained for the herpes simplex virus specific samples, indicating that anti-rotavirus IgA is selectively produced in breast tissue.

During the past decade rotaviruses have been shown to be a major cause of neonatal and infantile gastroenteritis throughout the world. They still constitute a great threat to young children, causing morbidity as well as mortality, particularly in those in developing countries. Breast feeding has been shown to protect neonates and infants from various infections. ${ }^{1}$ This protection extends to rotaviral gastroenteritis, at least to some extent, as lower incidences of viral diarrhoea have been found in breast fed infants. ${ }^{2}$ Newborns and infants in general under 6 months of age have been shown to have mild or asymptomatic rotaviral infection. ${ }^{3}$

Gut associated lymphoid tissue (as the local defence mechanism against this virus) consists of Peyer's patches and other lymphoid tissues in the intestine, including mesenteric lymph nodes. After antigenic stimulation in the gut primed B cells, particularly cells that produce $\operatorname{IgA}$, can migrate from there to various sites of external secretions, such as breast tissue, to produce local antibody there. ${ }^{4}$ This study was undertaken to determine the reason for relative resistance to rotaviral gastroenteritis in the newborn period by estimating the antibody transfer from the mother and also to explore the role of maternal gut associated lymphoid tissue against neonatal rotavirus infection.

\section{Patients and methods}

Preparation of antigen. For rotavirus antigen, human rotavirus strain Wa was grown and propagated in MA104 cells, then concentrated by precipitation with polyethylene glycol, and finally purified by sucrose gradient centrifugation. ${ }^{5}$ Protein concentration of the extract was $800 \mu \mathrm{g} / \mathrm{ml}$ as estimated by the Lowry method. For herpes simplex virus antigen, the HF strain of the virus type I was propagated in Vero cells and purified by sucrose gradient centrifugation. Protein concentration was estimated and diluted with carbonate buffer $(\mathrm{pH} \mathrm{9.5)}$ to obtain a final concentration of $2.5 \mu \mathrm{g} / \mathrm{ml}$ during use.

Samples. Breast milk, serum, and faecal samples were collected from 20 pairs of mothers and neonates. The mothers and babies were enrolled in the study at random according to delivery serials in the hospital, but very low birthweight babies and their mothers were excluded.

Samples of breast milk were collected three times: before beginning lactation and three days and seven days after lactation. These samples were first centrifuged at $2000 \mathrm{~g}$ for 10 minutes, and then upper lipid and lower cellular portions were discarded and recentrifuged at $4500 \mathrm{~g}$ for 30 minutes so that the middle portion could be collected. ${ }^{6}$ Each mother had a serum sample taken before lactation, and each 
neonate had serum samples taken before breast feeding began and seven days after breast feeding had started. Three faecal samples were taken from each neonate, one before breast feeding and one three days and one seven days after breast feeding had begun. The faecal samples were mixed with phosphate buffered saline, homogenised, and centrifuged at 10000 revolutions per minute for 30 minutes at $4^{\circ} \mathrm{C}$ to collect the supernatant fluid. Latex agglutination tests were performed on the faecal samples by using Rotalex kit (Orion Diagnostica, Denmark) to exclude asymptomatic rotaviral infection during the study. All the faecal samples yielded negative results, indicating the absence of rotavirus.

Enzyme linked immunosorbent assay. Immunolon microelisa plates (Dynatech, Virginia, United States) were used for measuring antibodies. IgA, secretory component, and $\mathrm{IgG}$ titres against rotavirus and herpes simplex virus were determined using the procedure we have reported previously. ${ }^{7}$ The rotavirus antigen was thawed and treated with sodium thiocyanate to increase its ability to attach to the solid phase. ${ }^{\gamma}$ To exclude the possibility of nonspecific reactions, antigen free plates were used as controls every time. Peroxidase conjugated rabbit immunoglobulins to human secretory component (Dako, Copenhagen, Denmark) were used at dilutions of 1:200. Peroxidase conjugated, affinity purified, heavy chain specific goat antibodies to human IgA and IgG (Tago, California) were used at dilutions of 1:500 and 1:2000, respectively.

Results of the assay were expressed with reference to standard curves. The standard curves were prepared separately for secretory component, $\operatorname{IgA}$, and $\mathrm{IgG}$ from several estimations of specific antibodies to twofold serial dilutions of different serum and colostral samples. Samples that had higher titres of antibodies were chosen as standards. The antibody titres of samples were decided in terms of the dilutions $\left(2^{n}\right)$ of standard samples, the optical density of which corresponded to that of the desired sample.

\section{Results}

Transfer of antibody from mother to neonate. Figure 1 shows the transplacental transfer and kinetics of rotavirus specific antibodies in the serum of the neonates. All the maternal serum samples contained high titres of $\operatorname{IgA}\left(2^{x \cdot 6+4}\right)$ as well as of $\operatorname{IgG}\left(2^{6 \cdot 2}\right)$. The IgG transfer $\left(2^{6 \cdot 25}\right)$ was almost in the same titre, whereas $\operatorname{IgA}$ transfer $\left(2^{1.57}\right)$ was low. Secretory component was not detectable in either maternal or neonatal serum samples.

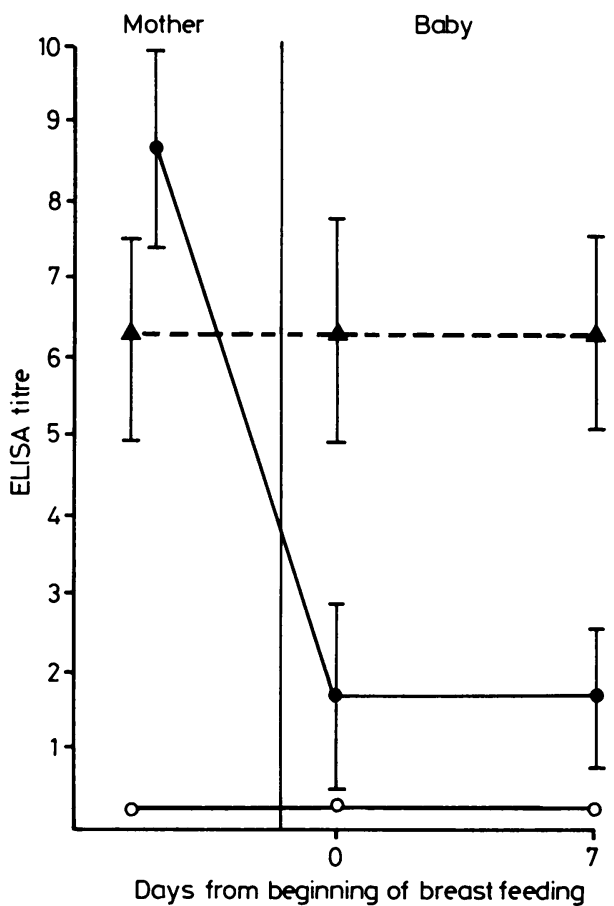

Fig. 1 Transplacental transfer and kinetics in the baby's serum of rotavirus specific antibodies. Enzyme linked immunosorbent assay titres of antibodies $\operatorname{Ig} A(\mathbf{O}-\mathbf{0})$, $\operatorname{Ig} G\left(250 \times 2^{\prime \prime}\right)(\mathbf{\Delta}----\mathbf{\Delta})$, and secretory component $\left(100 \times 2^{\prime \prime}\right)\left(2_{-}\right)$expressed in comparison with the standard curves. Vertical lines indicate standard deviations.

The titres of rotavirus specific antibody in breast milk are shown in Figure 2(a). Titres of $\operatorname{IgA}\left(2^{9 \cdot 15}\right)$ and secretory component $\left(2^{\mathrm{x} \cdot 75}\right)$ were present in high concentrations in all colostral samples, but the IgG titre $\left(2^{1 \cdot 67}\right)$ was low. All the antibody titres showed a rapid decrease in the samples taken three days after lactation, with a gradual decrease afterwards. On the other hand, antibody titres in neonatal faeces showed reverse trends. While we could not detect any antibody in the meconium (Fig. 2(b)), titres of rotavirus specific $\operatorname{IgA}\left(2^{4 \cdot 95}\right)$ and secretory component $\left(2^{3 \cdot 25}\right)$ were detected in significant amounts in the samples taken three days after breast feeding, which showed a further increase $\left(2^{6 \cdot 25}\right.$ and $2^{4 \cdot 35}$, respectively) by day 7 . IgG remained undetectable even after seven days of breast feeding. A definite correlation between rotavirus specific secretory component in breast milk and neonatal faeces was found ( $r=0.763$ ) (Fig. 3).

Ratios of serum IgA to breast milk IgA against rotavirus and herpes simplex virus. To clarify the 

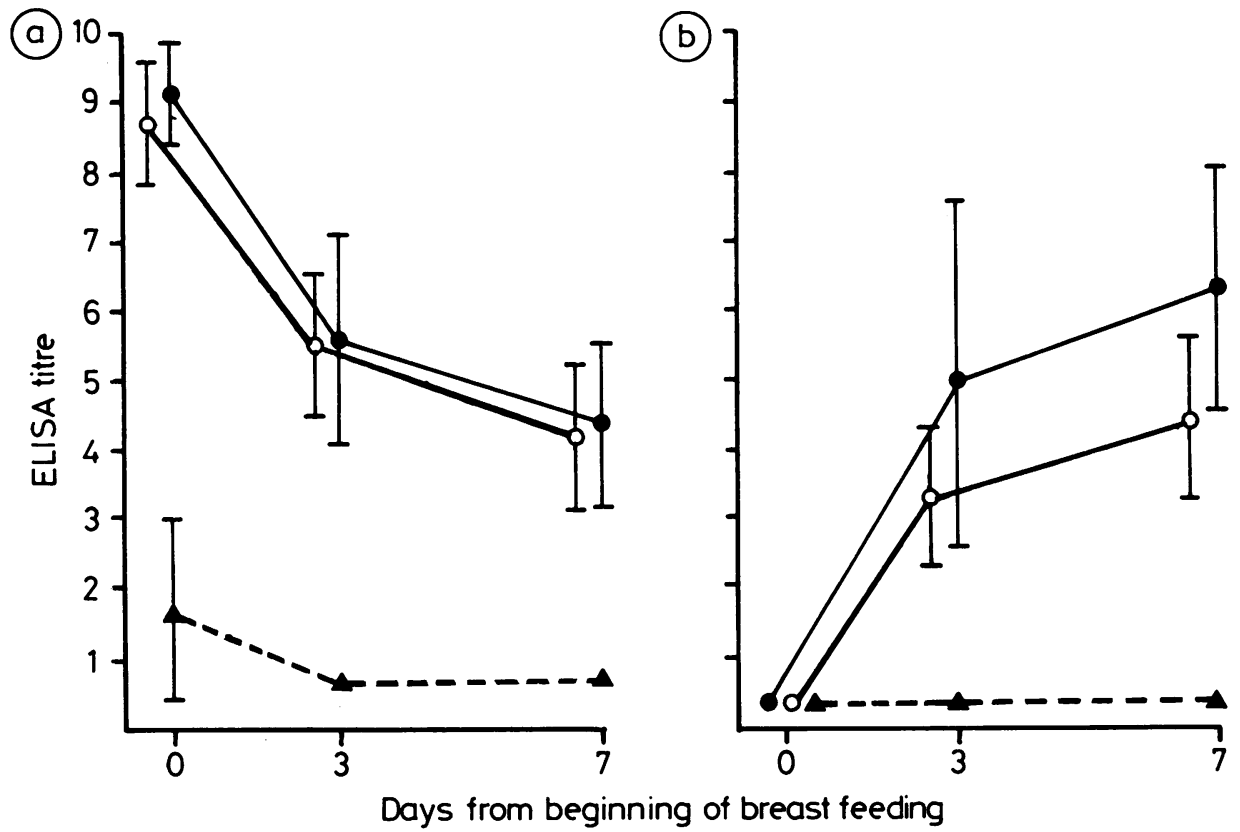

Fig. 2 Rotavirus specific antibodies $\operatorname{Ig} A(--O), \lg G(\mathbf{\Delta -}---\mathbf{\Delta})$, and secretory component $\left(\mathrm{O}_{-}-\mathrm{O}\right)$ in breast milk and baby's faeces. (a) Enzyme linked immunosorbent assay titres of antibodies $\operatorname{IgA}\left(1000 \times 2^{n}\right), \operatorname{Ig} G\left(40 \times 2^{n}\right)$, and secretory component $\left(200 \times 2^{n}\right)$ in breast milk; (b) titres of antibodies $\lg A, \operatorname{IgG}$, and secretory component $\left(100 \times 2^{n}\right)$ in baby's faeces. Titres expressed in comparison with the standard curves. Vertical lines indicate standard deviations.

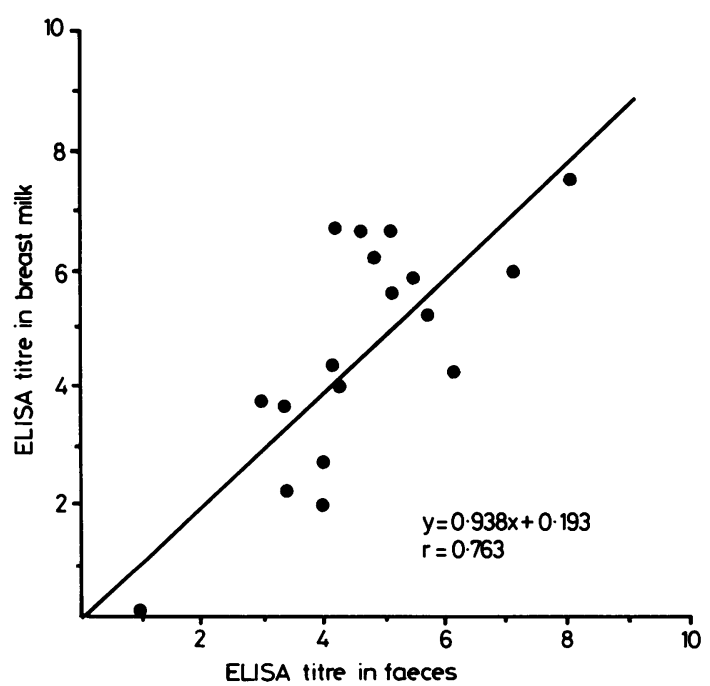

Fig. 3 Correlation between rotavirus specific secretory component in breast milk and baby's faeces. Enzyme linked immunosorbent assay titres in breast milk $\left(200 \times 2^{n}\right)$ and faeces $\left(100 \times 2^{n}\right)$ expressed in comparison with the standard curves. reason for high titres of rotavirus specific $\operatorname{IgA}$ in breast milk, we compared the ratios of serum to milk titres (Table). For comparison, the ratios were estimated in the same manner for herpes simplex virus, which cannot replicate in the gut. There was a significant difference (Student's $t$ test for paired groups) between the ratios of rotavirus specific IgA in maternal serum to breast milk and the herpes simplex virus specific ratios, the latter showing a higher value $(\mathrm{p}<0 \cdot 05)$. The mean (SD) serum: breast milk ratio was $2 \cdot 8(2 \cdot 1)$ for rotavirus and 4.5

Table Mean (SD) ratios of serum to breast milk IgA titres against rotavirus and herpes simplex virus type I

\begin{tabular}{|c|c|c|c|}
\hline \multirow[t]{2}{*}{ Virus } & \multicolumn{2}{|c|}{$\begin{array}{l}\text { ELISA titres of } \\
\text { antiviral } \lg A\left(2^{n}\right)\end{array}$} & \multirow{2}{*}{$\begin{array}{l}\text { Ratio of ELISA } \\
\text { titres (serum: } \\
\text { breast milk) }\end{array}$} \\
\hline & Serum ${ }^{\dagger}$ & Breast milk $\ddagger$ & \\
\hline $\begin{array}{l}\text { Rotavirus } \\
\text { Herpes simplex virus type } 1\end{array}$ & $\begin{array}{l}8.7(1.9) \\
7 \cdot 0(0 \cdot 7)\end{array}$ & $\begin{array}{l}5.9(1.9) \\
2.5(1.6)\end{array}$ & $\left.\begin{array}{l}2 \cdot 8(2 \cdot 1) \\
4 \cdot 5(1 \cdot 7)\end{array}\right\} *$ \\
\hline
\end{tabular}

ELISA = Enzyme linked immunosorbent assay.

${ }^{*} \mathrm{p}<0 \cdot 05$.

† Maternal serum at 250 times dilution.

$\ddagger$ At 1000 times’ dilution. 
(1.7) for herpes simplex virus. Thus rotavirus specific $\operatorname{Ig} \mathrm{A}$ in breast milk was significantly higher, indicating that the antibody is locally synthesised in breast tissue.

\section{Discussion}

Our results show that transplacental transfer of rotavirus specific $\operatorname{IgA}$ and $\operatorname{IgG}$ corresponds to the general antibody transfer as shown by other studies. ${ }^{9}$ Iyenger et al have shown that there is preferential transfer of IgG in comparison with $\operatorname{IgA}$ and $\operatorname{IgM} .{ }^{10} \mathrm{We}$ have observed that rotavirus specific IgG transfer is also preferential.

As far as the fate of rotavirus specific antibodies in breast milk fed to neonates is concerned, most of the $\operatorname{IgA}$ and secretory component were excreted in the faeces of the neonates. Before or during the process of excretion, these antibodies probably form a covering over the microvilli of the upper intestinal tract, giving passive protection, as shown by Nagura et al in the gastrointestinal tract of rats. ${ }^{11}$ Rotavirus specific IgA and secretory component detected in neonatal faeces after breast feeding are thought to be derived entirely from milk as no rotaviral outbreak occurred during the study and asymptomatic infections were also ruled out by negative latex agglutination tests in the faecal samples. Although the breast milk samples showed more diminished titres of antibodies than colostrum samples, faecal samples showed increased titres of $\operatorname{IgA}$ and secretory component. This is possibly due to the fact that the amount of milk taken by the neonate increased day by day, thus increasing the total antibody intake.

From our study, we have seen that all the mothers had high titres of rotavirus specific antibodies in breast milk and serum. This indicates that all of them had previous rotavirus infection, which corresponds to other studies, indicating the ubiquitous nature of the rotavirus and rotavirus specific antibodies. ${ }^{12}$ Titres of rotavirus specific IgA and secretory component in the colostral samples were much higher than in the serum samples. The $\operatorname{IgA}$ in breast milk is believed to be mainly secretory IgA in nature. This points us to the assumption that antirotavirus antibody is produced locally in the breast tissue by stimulation of $\operatorname{IgA}$ producing cells that have migrated from the gut associated lymphoid tissue, because direct infection of the mammary tissue with rotavirus does not occur. Antigens in the gut lumen are thought to stimulate the precommitted (IgA producing) lymphoid cells there, and some of these cells migrate to external secretory tissuesfor example, breast tissue-for production of antibody. ${ }^{4}$ Comparatively lower titres of breast milk antibody against herpes simplex virus, which cannot multiply in the gut, also support our hypothesis. Our previous study showed that there is anamnestic response for $\operatorname{IgA}$ production in the gut after reinfection with rotavirus. ${ }^{7}$ By some mechanisms, the reinfection in the gut may also cause production of specific secretory $\operatorname{IgA}$ in breast tissue.

Our study has the limitation that we have observed antibody titres for only seven days after lactation and after the start of breast feeding. But it suggests that if the initial rotavirus specific antibodies are high then the neonate may get passive protection in the intestinal tract for prolonged periods of breast feeding. Local antibodies to rotaviruses in the gut rather than systemic antibody are thought to be of primary importance in protection from infection. Animal studies have indicated that rotavirus infection occurs when the viral antigen titre exceeds the colostral neutralising antibody titre. ${ }^{13}$ The role of maternal breast milk IgA, in supplying local IgA to the gut in the early neonatal period, is immense and hence the role of maternal gut associated lymphoid tissue is indirectly also important.

We thank Professor K Watanabe and Dr S Isomura, Department of Pediatrics, Nagoya University School of Medicine, for valuable comments and for reviewing the manuscript.

\section{References}

1 Welsh JK, May TT. Anti infective properties of breast milk. J Pediatr 1979;94:1-9.

2 Simon A. Mata M. Anti rotavirus antibody in human colostrum Lancet 1978;i:39-40.

${ }^{3}$ Morishima T, Yamaguchi H, Nagayoshi S. Ozaki T. Isomura S. Suzuki S. Course of rotavirus gastro-enteritis in a closed community. Arch Dis Child 1980;55:147-9.

4 Thomas BT. The secretory immune system. Basic and clinical immunology. 4th ed. Los Altos, California: Lange Medical Publications, 1982.

5 Nagayoshi S, Yamaguchi H, Ichikawa T, et al. Changes of the rota virus conc. in feces during the course of acute gastroenteritis as determined by IAHA test. Eur J Pediatr 1980;134:99-102.

' Barbara T. Totterdell BM. Chrystic IL, Banatvala JE. Cord blood and breastmilk antibody in neonatal rotavirus infection. Br Med J 198();280:828-30).

7 Yamaguchi H, Inouye S, Yamauchi M, Morishima T. Anamnestic response in fecal $\lg A$ production after rotaviral infection of infants. J Infect Dis 1985;152:398-400.

* Inouye S, Matsuno S, Yamaguchi H. Efficient coating of the solid phase with rotavirus antigens for ELISA of $\operatorname{IgA}$ antibody in feces. J Clin Microbiol 1984;19:259-63.

"Ogra SS, Wcintraub D. Ogra PL. Fatc and absorption of cellular and soluble components in the Gl tract of newborn. J Immunol 1977;119:245-8.

11) Iyenger L. Selvaraj RJ. Uptake of antibodies by intestines of the newborn infant. Arch Dis Child 1972;47:411-4 
"Nagura H, Nakane PK. Brown WR. Breast milk IgA binds to jejunal epithelium in suckling rats. $J$ Immunol 1978:120:1333-9.

12 Black RE. Greenburg HB. Kapikian AZ. Brown KH, Becker S. Acquisition of serum antibody to Norwalk virus and rotavirus and relation to diarrhea in a longitudinal study in rural Bangladesh. J Infect Dis 1982;145:483-9.

13 Snodgrass DR, Fahey KJ, Well PW, Campbell I. Whitelaw A Passive immunity in calf rotavirus infections:maternal vaccina- tion increases and prolongs IgA antibody secretion in milk. Infect Immun 1980;28:344-9.

Correspondence to Dr M M Rahman. Department of Pediatrics, Nagoya University School of Medicine, 65. Tsurumai-Cho, ShowaKu. Nagoya - 466. Japan.

Received 29 October 1986

\title{
Fifty years ago
}

\section{Plasma phosphatase in the diagnosis of rickets}

\author{
Noah Morris, Mary M Stevenson, Olive D Peden, and Jean M D Small (Glasgow)-Arch Dis Child \\ 1937;12:45-58
}

Plasma phosphatase was measured in 506 children in the first two years of life, all of whom had manifest rickets or might have been deficient in vitamin D. Raised values were found in $84 \%$ of cases with clinical or $x$ ray evidence of rickets, and a high plasma phosphatase value was more often associated with rickets than a reduced serum phosphorus concentration. In general the phosphatase activity ran parallel with the degree of rickets, but the correlation was not a close one. While healing of the rickets was associated with a fall in the phosphatase activity, in no case did this precede radiological evidence of healing. In fact, the initiation of antirachitic therapy was occasionally followed by a transient rise in the plasma phosphatase. The authors postulated that the rare occurrence of a normal phosphatase activity with signs of active rickets might be explained on the assumption that growth had temporarily stopped, while the presence of a high plasma phosphatase activity in the absence of evidence of rickets could be attributed to an insufficient supply of calcium to meet the demands of active bone cells. Rise in the plasma phosphatase activity was considered to be an earlier manifestation of rickets than any provided by clinical or radiological examination and also a more sensitive test than the fall in serum phosphorus or the calcium-phosphorus product.

Comment. This was one of the earliest reports on the value of the plasma phosphatase activity in the diagnosis of early rickets. The conclusion that the alkaline phosphatase activity rises before there are radiological changes may be erroneous, and the earliest sign of rickets is probably loss of radiological definition of the metaphyseal ends of long bones such as the radius and ulna. Interpretation of minor $x$ ray changes is open to the criticism, however, that it is highly subjective. The much more recent ability to measure the plasma 25 -hydroxycholecalciferol concentration probably supplies us with a more reliable index of the vitamin $D$ state of a community.

(Noah Morris was biochemist to the Royal Hospital for Sick Children in Glasgow. He was responsible for introducing a series of young graduates to the excitements of research in paediatrics; two of these later occupied chairs in paediatrics and one a chair in pathology. Shortly after publication of this paper Morris was appointed to the Chair of Materia Medica in Glasgow and he devoted the rest of his too short life to clinical practice and research in adult medicine. His book, 'Acidosis and alkalosis', written in conjunction with Professor Stanley Graham, was a minor classic in the 1930s when few British paediatricians appreciated the value of biochemistry to the clinician.) 